Bangl. J. Vet. Med. (2006). 4 (1): 43-46

\title{
DETERMINATION OF EFFICACY OF THERMOSTABLE PPR LIVE HOMOLOGOUS VACCINE INCUBATED AT ROOM TEMPERATURE FOR 14 DAYS
}

\author{
M. P. Siddique ${ }^{* 1}$, M. B. Rahman ${ }^{1}$, S. M. Z. H. Chowdhury ${ }^{2}$, M. A. Kafi ${ }^{1}$ and M. S. Alam ${ }^{2}$ \\ ${ }^{1}$ Department of Microbiology and Hygiene, Faculty of Veterinary Science, Bangladesh Agricultural University, \\ Mymensingh-2202, ${ }^{2}$ Animal Health Research Division, Bangladesh Livestock Research Institute, Savar, Dhaka, \\ Bangladesh
}

\begin{abstract}
The study was undertaken during the period from July to November 2005, for the first time, to determine the efficacy of thermostable PPR vaccine incubated at $-20^{\circ} \mathrm{C}$ and room temperature (RT) for 14 days which was developed by Bangladesh Livestock Research Institute (BLRI), Savar, Dhaka, in collaboration with and Livestock Research Institute (LRI), Mohakhali, Dhaka. A total of 80 healthy goats of both sexes, aged between 8 to 36 months were divided into three groups as A, B and C. Group A and B comprised of 30 goats each and received thermostable PPR vaccine kept at $-20^{\circ} \mathrm{C}$ and at room temperature (RT) respectively for 14 days, at a dose rate of $1 \mathrm{ml}\left(4 \log _{10} \mathrm{TCID}_{50} / \mathrm{ml}\right)$ per goat subcutaneously while group $\mathrm{C}$ comprising 20 goats served as non-vaccinated control. At 30 days postvaccination, 3 goats from each vaccinated and non-vaccinated group were challenged with $1 \mathrm{ml}\left(5 \mathrm{GID}_{50}\right)$ of virulent PPR virus per goat subcutaneously in the mid cervical region. Sera samples were collected from all the groups at pre- and post-vaccination (15 and 30 days postvaccination) and were tested for anti-PPR antibody by competitive enzyme linked immunosorbent assay (C-ELISA). In case of group A, average percent inhibition (PI) values of the sera samples at prevaccination and at 15- and 30 days post vaccination were $11.0 \pm 5.7,62.8 \pm 9.9$ and $81.5 \pm 5.9$ respectively and in case of group $\mathrm{B}$, were $10.0 \pm 4.1,60.7 \pm 9.4$ and $79.3 \pm 7.2$ respectively, which were significantly $(\mathrm{p}<0.01)$ higher than those of nonvaccinated control goats $(6.3 \pm 3.4,10.2 \pm 3.3$ and $13.6 \pm 3.7$ respectively). The titres of vaccinated goats gradually increased until 30 days postvaccination. The challenge test with virulent PPR virus at 30 days post vaccination showed that the thermostable PPR vaccine with both incubation temperatures at $-20^{\circ} \mathrm{C}$ and $\mathrm{RT}$ for 14 days protected all the goats $(100 \%)$ of groups A and B respectively while all the non-vaccinated control goats were not protected after challenge showing clinical signs of PPR and / or mortality. From the above findings it may be concluded that the thermostable PPR vaccine can be kept at normal environmental temperature $\left(25^{\circ}-30^{\circ} \mathrm{C}\right)$ as long as 14 days without loss of its potency and may be used to prevent PPR in goats in field condition.
\end{abstract}

Key Words: Thermostable PPR vaccine, efficacy, C-ELISA

\section{INTRODUCTION}

Peste des Petits Ruminants (PPR), also known as pseudorinderpest, goat plague, Kata, pneumoenteritis complex, goat catarrhal fever (Chakrabarti, 2003), is a viral disease of small ruminants (sheep and goats) characterized by an erosive stomatitis, a catarrhal inflammation of the ocular and nasal mucous membranes, profuse diarrhoea, mortality may reach up to $60-70 \%$. In Bangladesh, the PPR virus was identified during a severe outbreak in 1993 (Sil et al., 1995) which was further confirmed by World Reference Laboratory and found that the virus has a close relation with Indian isolates (West Bengal) of PPR virus at a cluster with Asian group (Barrett et al., 1997). PPR being an exotic disease in Bangladesh, there is a very little knowledge about its epidemic nature, diagnostic techniques and control strategy (Sil et al., 2000-2001). A control programme using locally produced tissue culture live attenuated rinderpest vaccine (TCV), as well as imported rinderpest vaccine were adapted against PPR in this country, but failed (Sil et al., 1995). To overcome the problem, a homologous PPR live vaccine was developed, but the main disadvantage of this vaccine, like other Morbillivirus vaccine, is its poor thermal stability (Diallo, 2002). Although, lyophilization and stabilizing excipients have conferred marginal stability on many vaccines, the development of adequately thermostable vaccine has historically been hindered by the inherent lability and complex nature of the vaccine entities (Rexroad et al., 2002). To solve this problem, a thermostable PPR vaccine has been developed experimentally by scientists of BLRI and DLS (Chowdhury et al., 2004). Therefore, the present study was undertaken for the first time in Bangladesh, to determine the efficacy of the thermostable PPR vaccine incubated at room temperature for 14 days.

${ }^{*}$ Corresponding author.

Copyright $(2006$ Bangladesh Society for Veterinary Medicine

All rights reserved 1729-7893/0090/06 


\section{MATERIALS AND METHODS}

\section{Vaccine and vaccination}

A thermostable PPR live homologous vaccine developed by Bangladesh Livestock Research Institute (BLRI), Savar, Dhaka, in collaboration with and Livestock Research Institute (LRI), Mohakhali, Dhaka (Chowdhury et al., 2004) was used in this study. A total of 80 healthy goats from 2 villages (Monidia and Chakhalgram) at Savar, Dhaka, of both sexes, aged between 8 to 36 months were divided into three groups as A, $\mathrm{B}$ and C. Group A and B comprised of 30 goats each and received thermostable PPR vaccine kept at $-20^{\circ} \mathrm{C}$ and at room temperature (RT) respectively for 14 days, at a dose rate of $1 \mathrm{ml}\left(4 \log _{10} \mathrm{TCID}_{50} / \mathrm{ml}\right)$ per goat subcutaneously while group C comprising 20 goats served as non-vaccinated control. Serum analysis with competitive enzyme linked immunosorbent assay (C-ELISA) was done before vaccination to found PPR antibody negative goats. Whole blood samples were collected by disposable plastic sterile syringes from all the groups at prevaccination and at 15 and 30 days post vaccination. The sera samples were stored at $-20^{\circ} \mathrm{C}$ until tested.

\section{C-ELISA}

A commercial PPR C-ELISA kit, jointly produced by BDSL, Flow Laboratories and Institute for Animal Health, Pirbright, Surrey, England was used for ELISA test of the sera collected from vaccinated and nonvaccinated goats. The kit was based on a standard competitive enzyme-linked immunosorbent assay (C-ELISA) technique to determine the presence of anti-PPR antibody in serum as described by Anderson et al. (1991). The mean PI (percent inhibition) values were calculated as follows:

$$
\mathrm{PI}=100-\left[\frac{\text { Replicate Optical Density (OD) of Test Sera }}{\text { Mean OD of Mab-control }} \times 100\right]
$$

The test was accepted when the OD values of Mab-control and PI values of different controls fall within the accepted limits, according to Quality Assurance (QA) Fact Sheet of the C-ELISA kit (PI values $\geq 50$ indicated positive and $\leq 50$ indicated negative).

\section{Challenge test}

For challenge test, a field pathogenic PPR virus isolated from a PPR affected goat of Gazipur district was used and was collected from Animal Health Research Division of Bangladesh Livestock Research Institute (BLRI). At 30 days post vaccination, 3 goats from each vaccinated and control group were brought to BLRI isolation unit and challenged with $1 \mathrm{ml}$ of virulent PPR virus (PPR virus positive processed $20 \%$ tissue homogenate, 5 GID $_{50} /$ $\mathrm{ml}$, Chowdhury et al., 2004) subcutaneously in the mid cervical region. The goats were observed daily for recording rectal temperatures, clinical signs, mortality and postmortem lesions (from dead goats) up to 30 days postchallenge.

\section{Statistical analysis}

Student's 't'-test and one-way 'ANOVA' (Sprinthall, 1987) were carried out to determine the significance of variation of PI values among the different groups and within the individual vaccinated group at pre- and postvaccination (at 15 and 30 days postvaccination).

\section{RESULTS AND DISCUSSION}

Average PI values of sera samples from non-vaccinated control goats (group C) at prevaccination and at 15and 30 days postvaccination were $6.3 \pm 3.4,10.2 \pm 3.3$ and $13.6 \pm 3.7$ respectively (Table 1), which were negative to PPR antibody (P.I. value $<50$ indicates negative). This variation in the mean PI values of control group at different periods of sera collection, were statistically insignificant $(p<0.001)$ and this minor variation might be due to the managemental system as the study was undertaken at field level. In case of group A (vaccinated with thermostable PPR vaccine kept at $-20^{\circ} \mathrm{C}$ ), average PI values of the sera samples at prevaccination and at 15 and 30 days postvaccination, were $11.0 \pm 5.7,62.8 \pm 9.9$ and $81.5 \pm 5.9$ respectively, which were significantly $(\mathrm{p}<0.01)$ higher than those of non-vaccinated control goats. The PI values gradually increased until 30 days postvaccination. This finding is similar with the reports using normal lyophilized PPR 


\section{Efficacy of thermostable PPR vaccine}

vaccine (Sil and Taimur, 2001; Razzaque et al., 2005) where the authors concluded that following vaccination, the antibody titres gradually increased from day to day. In case of group B (vaccinated with thermostable PPR vaccine kept at RT), average PI values of the sera samples at prevaccination and at 15 and 30 days postvaccination, were $10.0 \pm 4.1,60.7 \pm 9.4$ and $79.3 \pm 7.2$ respectively, which were significantly $(\mathrm{p}<0.01)$ higher than those of non-vaccinated control goats and also gradually increased until 30 days postvaccination.

Table 1. Comparative mean PI values of antibody responses in goats following vaccination with thermostable $\mathrm{PPR}$ vaccine kept at $-20^{\circ} \mathrm{C}$ and room temperature (RT)

\begin{tabular}{|llllll|}
\hline Groups & Vaccination status & Storing status & PI values & \\
\cline { 4 - 5 } & & & Prevaccination & \multicolumn{2}{l|}{ Postvaccination } \\
\cline { 4 - 5 } & & & \multicolumn{1}{l}{15 days } & 30 days \\
\hline A $(\mathrm{n}=30)$ & Vaccinated & $-20^{\circ} \mathrm{C}$ & $1.4-18.5^{\mathrm{a}}$ & $46.9-74.9$ & $68.9-91.2$ \\
& & & $11.0 \pm 5.7^{\mathrm{b}}$ & $62.8 \pm 9.9^{* *}$ & $81.5 \pm 5.9^{* *}$ \\
$\mathrm{~B}(\mathrm{n}=30)$ & Vaccinated & $\mathrm{RT}$ & $1.8-15.7$ & $45.1-72.9$ & $66.5-89.0$ \\
& & & $10.0 \pm 4.1$ & $60.7 \pm 9.4^{* *}$ & $79.3 \pm 7.2^{* *}$ \\
$\mathrm{C}(\mathrm{n}=20)$ & Non-vaccinated & - & $2.0-16.3$ & $5.8-20.0$ & $9.6-24.4$ \\
& control & & $6.3 \pm 3.4$ & $10.2 \pm 3.3$ & $13.6 \pm 3.7$ \\
\hline
\end{tabular}

$\mathrm{PI}=$ Percent inhibition, $\mathrm{n}=$ Number of sera samples, ${ }^{\mathrm{a}}$ Range, ${ }^{\mathrm{b}}$ Mean $\pm \mathrm{SD}$ and $* *$ Significant at $\mathrm{p}<0.01$.

Table 2. Results of challenge test in goats vaccinated with thermostable and normal lyophilized PPR vaccines of different incubation temperatures for 14 days

\begin{tabular}{|c|c|c|c|c|c|c|c|}
\hline \multirow[t]{2}{*}{ Groups } & \multirow[t]{2}{*}{ Vaccination status } & \multirow[t]{2}{*}{ Storing status } & \multirow[t]{2}{*}{$\begin{array}{l}\text { No. of goats } \\
\text { challenged }^{\#}\end{array}$} & \multicolumn{2}{|c|}{$\begin{array}{l}\text { Goats } \\
\text { protected }\end{array}$} & \multicolumn{2}{|c|}{$\begin{array}{l}\text { Goats } \\
\text { not protected }\end{array}$} \\
\hline & & & & No. & $\%$ & No. & $\%$ \\
\hline $\mathrm{A}(\mathrm{n}=30)$ & Vaccinated & $-20^{\circ} \mathrm{C}$ & 3 & 3 & 100 & 0 & 0 \\
\hline$B(n=30)$ & Vaccinated & RT & 3 & 3 & 100 & 0 & 0 \\
\hline$C(n=20)$ & $\begin{array}{l}\text { Non-vaccinated } \\
\text { control }\end{array}$ & - & 3 & 0 & 0 & 3 & 100 \\
\hline
\end{tabular}

${ }^{\#}$ Goats of different groups were challenged at 30 days postvaccination.

Results of challenge test (Table 2) revealed that the thermostable PPR vaccines of both incubation temperatures $\left(-20^{\circ} \mathrm{C}\right.$ and RT) for 14 days protected $(100 \%)$ all challenged goats without any clinical signs of PPR and mortality, even at 30 days postchallenge. The challenged non-vaccinated control goats started to show clinical signs like rise of body temperature from 4-6 days postchallenge which is in agreement with the finding of Taylor (1984). The phases of clinical sings and its duration, found in this study, were similar with the findings of Khan et al. (2005). Postmortem reports included enlarged lymphnodes, congestion and consolidation of lungs, zebra-stripping in caeco-colic junction, which support the findings of Khan et al. (2005).

From the above findings, it may be concluded that the thermostable PPR vaccine can be kept at normal environmental temperature $\left(25^{\circ}-30^{\circ} \mathrm{C}\right)$ as long as 14 days without loss of its potency and this vaccine can be used at field level to prevent PPR in Bangladesh. 


\section{REFERENCES}

1. Anderson J, Mckay JA and Butcher RN (1991). The use of Mabs in C-ELISA for the detection of antibodies to rinderpest and peste des petits ruminant viruses. Panel proceedings IAEA-SM-318. International Symposium on Nuclear and related Techniques in Animal Production and Health, Vienna, Austria.

2. Barrett T, Pronob D, Sreenivasa BP and Corteyn M (1997). Recent epidemiology of PPRV. Veterinary Microbiology 88: 125-130.

3. Chakrabarti A (2003). A Textbook of Preventive Veterinary Medicine. $3^{\text {rd }}$ edn., Kalyani Publishers, New Delhi, India.

4. Chowdhury SMZH, Shukur A, Nasiruddin M, Ara MR, Ferdous KS, Sobhan Z, Habib S, Das BK and Litamoi JK (2004). Molecular characterization of PPR virus: Experiential development of PPR thermostable vaccine. Annual Research Review Workshop-2004, Bangladesh Livestock Research Institute, Savar, Dhaka, 9-10 May 2004.

5. Diallo A (2002). Control of PPR: Classical and new generation vaccines. Vaccines for OIE List-A and emerging animal diseases. Proceeding of a symposium. Ames, Iowa, USA. September 16-18, 2002.

6. Khan MR, Haider MG, Alam KJ, Hossain MG, Chowdhury SMZH and Hossain MM (2005). Pathological investigation of PPR in goats. Bangladesh Journal of Veterinary Medicine 3: 134-138.

7. Razzaque MA, Rahman MB, Kafi MA, Islam MR and Amin KMR (2005). Antibody responses in ruminants species following vaccination with tissue culture adapted PPR vaccine. Proceedings of $21^{\text {st }}$ Annual Conference of Bangladesh Society of Microbiologist. 1-2 July 2005, BINA, Mymensingh, Bangladesh.

8. Rexroad J, Christopher M, Latoyo S, Jones C and Russel M (2002). Lyophilization and thermostability of vaccines. Cell Preservation Technology 1: 91-204.

9. Sil BK and Taimur MJFA (2001). Final report of the contract research project on production of peste des petits ruminants (PPR) vaccine and its field application. BARC funded project, BLRI, Savar, Dhaka, June 2001.

10. Sil BK and Taimur MJFA (2001). Final report of the: Contract research project on production of peste des petits (PPR) vaccine and its field application. BARC funded project, BLRI, Savar, Dhaka, June 2001.

11. Sil BK, Rahman MM, Taimur MJFA and Sarker AJ (1995). Observation of outbreaks of PPR in organized goat farms and its control strategy. Presented at the Annual Conference of the Bangladesh Society for Veterinary Education and Research. December 3, 2005, BARC, Dhaka.

12. Sil BK, Taimur MJFA, Ershaduzzaman M, Hossain KM, Sarker AJ, Debnath NC and Alam MR (1999). Comparative trial of experimental vaccine candidate (Avirulent mutant) with rinderpest live vaccines. Bangladesh Journal of Livestock Research 6: 18-22.

13. Sil BK, Taimur MJFA, Hossain KM, Giasuddin M, Haque ME, Chowdhury ER, Alam MR and Sarker AJ (2000- 2001). Preliminary study towards the development of inactivated PPR vaccine. Bangladesh Journal of Livestock Research 7- 8: $1-6$.

14. Sprinthall RC (1987). Basic Statistical Analysis. $2^{\text {nd }}$ edn., Prentice-Hall Inc., A Division of Simon and Schuster, Engkewood Cliffs, New Jersey 07632.

15. Taylor WP (1984). The distribution and epidemiology of PPR. Preventive Veterinary Medicine 2: 157-166. 